ISLLAC

Journal of Intensive Studies on Language, Literature, Art, and Culture

Vol. 1 No. 1 September 2017

\title{
CULTURE RECOGNITION THROUGH SOCIOLOGY LEARNING FOR TIMOR LESTE STUDENTS
}

\author{
Sebastião Periera \\ Email: santosagostinho@yahoo.com \\ Instituto Superior Cristal Dili Timor Leste
}

\begin{abstract}
This paper aims to describe the introduction of culture through sociology learning for Timor Leste students. In essence, every society has a different culture with other communities. The culture serves to regulate and meet the needs of the people living their owners. The people of Timor Leste have different cultures from other communities. This difference is due to differences in the environment and subsystems of communities in Timor-Leste. Every member of the community needs to understand and live the culture in order to overcome the problems faced in life. In the world of education, cultural understanding can be obtained through learning Sociology. Therefore, sociology subject matter that is filled with community culture can provide significant benefits to the students.
\end{abstract}

Keywords: culture, sociology learning, Timor Leste students

\section{INTRODUCTION}

Culture is any type of human activity and the result is patterned, both the unaffected and the unaffected (Sadtono, 2002: 16). In line with that opinion, culture can be grouped into two major pillars, namely culture as product and culture as the whole way of life of society. As a product, cultures include tangible values, beliefs, norms, symbols, and ideologies, while as a way of life, a culture of human relations and human attitudes or behavior in relationships with others (Thompson 1990:1).

The anthropologists divide the culture into two, the great culture and the small culture. Great culture is a culture of achievement, which includes geography, history, institutions, literature, art, music, and way of life. Meanwhile, a small culture is a culture of behavior, which includes attitudes, beliefs, perceptions, especially those expressed in language and influenced by local culture (Tomalin and Stempleski, 
ISLLAC

Journal of Intensive Studies on Language, Literature, Art, and Culture

Vol. 1 No. 1 September 2017

1993). In this case, culture is inherited through human action in the form of a prominent interaction and language communication.

Culture is something that can be taught. In other words, culture is knowledge of the world. This suggests that members of the culture are not just knowing certain facts or recognizing objects, places, and people. However, they must also share the mindset, the way of understanding the world, as well as the withdrawal of inferences and predictions. Goodenough (in Keesing, 1992) asserts that as a culture, knowledge provides a benchmark to determine what, to what, to determine how we feel, to determine what to do about it, and to determine how to do it.

Based on the above description, it can be argued that the essence of culture with regard to the way of human life. Therefore, this culture includes three beings concerning what man does, what he knows or thinks about, and what he makes or uses to meet his life's needs. These three manifestations by Spradley (1985) are mentioned in terms of cultural behavior, cultural knowledge, and cultural objects. He explained that although cultural behavior and cultural objects can be seen easily, the two forms only reflect the surface. In fact, the more fundamental and more important are the hidden ones as cultural knowledge because that knowledge shapes the behavior and interprets its experiences.

Sociology is a science that studies the interrelationships between various kinds of social phenomena, such as economic phenomena with religion, a law with morals, a law with economics, the movement of society with politics and so on. Sociology can also be said to study the science of human interaction in society or group. Learn sociology to examine various social symptoms, social structure, or the process of community life. Therefore, this lesson is actually an interesting lesson for students because the lesson is related to the students' lives in interacting in the community. Learners will be easy in taking samples of each material taught and apply the lessons of sociology in a real way, that is when learners live and establish social relationships in society.

Sociology is a science whose object of study is society. By studying sociology, can be known various social symptoms and the process of occurrence. Sociology not 
ISLLAC

Journal of Intensive Studies on Language, Literature, Art, and Culture

Vol. 1 No. 1 September 2017

only examines the community on the village scope that is thick to the values of kinship, but also urban with various social phenomena that appear therein. Various social aberrations are also discussed in sociology lessons that are very interesting to explore further.

Various things above is an interesting side of sociology lessons which became one of the reasons sociology becomes a fun lesson for learners. Sociology that contains the material and memorizing the many can be a matter of boring or even fun depending on the process of delivering material done by educators during the learning process. Even in the field, there are learners who love the lessons of sociology because the subject matter is not foreign to him and it is said that sociology becomes a refresher lesson.

The lesson of sociology will be a fun lesson when taught in a fun way. Through interesting learning, learners will become excited and motivated to study harder. Feelings of pleasure or not learners on a subject also determine success in learning. Therefore, it is necessary to understand and think of ways and learning process that can make learning fun for learners.

\section{UNDERSTANDING CULTURE}

Tylor as quoted by Saifuddin (2005: 23) views culture as the totality of human experience. Therefore, he says that culture is a complex totality that includes knowledge, beliefs, art, morals, laws, customs, and capabilities and other habits possessed by humans as members of society. These cultural elements are shared by all peoples of the world. This means that no single society lives without culture. The universal cultural elements by Koentjaraningrat (2003: 80-81) are classified into 7 groups, namely language, knowledge system, social organization, living equipment system and technology, life-saving livelihood system, religious system, and arts. Each element of the universal culture also has three forms, namely cultural systems, social systems, and elements of physical culture. For example, the religious system has manifested itself as a belief system and idea of God, gods, sublime spirits, etc., has a ceremonial form and prepares sacred objects. 
ISLLAC

Journal of Intensive Studies on Language, Literature, Art, and Culture

Vol. 1 No. 1 September 2017

Culture is the whole of society's order in relation to beliefs, attitudes, customs, behaviors, social customs, etc. (Richards, Platt, and Platt, 1993). The order intended in that sense is the system. Man in his life in society has rules that regulate the behavior of human life. Culture is the context that directs the behavior of every individual in the life of society. Condon (1973) explains that in human life in society there is an integrated pattern system called culture.

The people of Timor Leste have different cultures from other cultures. The culture of the people of Timor-Leste, as well as other societies, serves to organize and meet the needs of the community. The complexity of Timor Leste society shows that in society there are a number of cultural subsystems belonging to different communities, such as cultural subsystems for economic communities, regional communities, social communities, and so forth. Porter and Samovar (2005) explains that there are differences between each cultural subsystem owned by one community with other community culture subsystems in one culture or society that encompasses it.

The culture of the people of East Timor fulfills the need of the community to overcome its problems in living. Sumardjo (2005) explains that culture must be viewed in a juxtaposition, in the sense that one culture is in line with other culture in parallel position. Therefore, a culture of a society can not be judged from the point of view of other peoples cultures. This is different from civilization. Civilization refers to the advanced level of science and technology. The civilization of a society can be compared with other societies. The progress of a civilization can be seen and measured because there are clear parameters.

\section{CULTURAL IDENTITY}

Cultural identity has to do with the origin or tradition of society. Identity gives meaning and characteristic of a particular culture (check Liliweri 2003). At the level of interpersonal relationships, the notion of identity refers to the way of putting one person into another's place (empathetic communication). At this level, identity is understood as a way of identifying (through an understanding of identity) or detailing 
ISLLAC

Journal of Intensive Studies on Language, Literature, Art, and Culture

Vol. 1 No. 1 September 2017

what is seen, heard, known or described, including identifying physical characteristics, even identifying a person's mind with an influencing school.

Identity is often based on the role that the members of the community or community have in carrying out cultural practices. Sociologically, roles can be interpreted as a set of cultural expectations of a particular position. Schneider (2000) explains that (1) the role is more referring to expectations, not just the actual behavior, and (2) the role is more normative, not just descriptive. For example, someone is said to have a director role if he displays his or her identity, personality, verbal and nonverbal behavior as a director.Roles are closely related to cultural structures and social structures. The Cultural structure is a pattern of perception, thoughts, and feelings, while social structures are patterns of social behavior. In this case, cultural identity is a breakdown of the characteristics or characteristics of a culture possessed by a group of speakers who are known to their limits when compared to other speakers' characteristics or cultural characteristics. This means that to identify the cultural identity of the people of Timor-Leste is not enough to be based only on physical characteristics, but also to consider the order of thinking, feeling and acting of a society.

The sociocultural identity of a society can be imposed on gender identity, an identity of age, race, ethnicity, religion, class, nation, region, and person. Through such identity groupings, social categories and social stratification are created. What is meant by social category is the category of a society based on certain social identities which are supposed to be able to display certain intercultural communication pattern also. Meanwhile, social stratification is concerned with the way society views the social layers formed due to differences of domination in intergroup relations (Liliweri, 2003: 91).

To indicate that a community has an identity that is different from that of another community, a means which symbolizes the difference of identity is required. Harris and Moran (2005: 58-62) identify there are several things that can be used to examine the differences of the community. It includes (a) communication and language, (b) clothing and appearance, (c) food and eating habits, (d) time and 
ISLLAC

Journal of Intensive Studies on Language, Literature, Art, and Culture

Vol. 1 No. 1 September 2017

awareness of time, (e) appreciation and recognition, (f), (g) values and norms, (h) sense of self and space, (i) mental processes and learning, and (j) beliefs and attitudes.

In community life, a community characteristic that is directly recognizable is the distinctive characteristic of communication systems and appearance systems in society. Communication systems, both verbal and nonverbal, distinguish a community from other communities. The language used by the education community is different from the language used in the military community. Likewise in terms of self-appearance, it can be immediately recognized by the community where the person is. These appearances include clothing and outfits as well as body decorations that tend to differ culturally. The hijab is the Islamic community, the one who wears the crucified necklace is the Christian community, and so on.

The awareness of time varies between cultures with one another. Some people are punctual and others rarely time. Lewis (2004: 51-57) explains that cultures adhere to diverse world views, as well as varying concepts to paint a kaleidoscopic view of the nature of reality. There is a culture that has the concept that time is linear, but there is also a culture that views that time is cyclic. The concept that time is linear is owned by people who are multi-active, ie people who are linearly active. Generally, this attitude is shared by Western culture. Meanwhile, the concept that time is cyclic is owned by people of a culture that view time in harmony with a cyclic event of nature, namely that it will return to the future.

Every society has different needs so that they have different values for what is needed and what to do. There is a culture that values friendship more than matter, but there is also a culture that is more important to matter because it is necessary to improve the welfare of their lives. These values affect the attitude of individuals in carrying out their activities in community life.

\section{CULTURE VALUES OF COMMUNITY}

The system of cultural values is a core value in human life. These values are upheld, respected, and adhered to in social life. This value system is a rule that directs the behavior of community members in carrying out socio-cultural activities. 
ISLLAC

Journal of Intensive Studies on Language, Literature, Art, and Culture

Vol. 1 No. 1 September 2017

Koentjaraningrat (2003) mentions that the cultural value system serves as the ultimate guideline for human behavior. These values have been attached to each member of society so that it is difficult to change or change in a short time because it concerns the main issues for human life (Sukidin, Basrowi, and Wiyaka, 2003: 10-11).

In addition to cultural values, in life in society, there are cultural norms. These values and norms are essentially societal rules that control and regulate the socio-cultural activities of a society. These values and cultural norms serve as guidelines and guidelines for life that are upheld and obeyed by all members of the community. Cultural values are abstract and contain ideas that are considered good, true and shared by community members. Because the value of culture is abstract and general, it is possible the occurrence of various social behaviors that vary between members of one society to another. As long as the diversity of behaviors is in accordance with the values held, the conflict between members of the community in the same ethnic will not happen. Meanwhile, cultural norms are a more specific guideline for cultural behavior. In this case, norms regulate and direct the way people behave, think, speak to individual members of society in certain situations (Conklin, 1984).

The values and cultural norms of a society always regulate and direct the way individuals individual members of the community in behaving and acting in accordance with the expected by the community. These values and cultural norms are reflected in the cultural views and attitudes of community members in carrying out cultural practices. The views and cultural attitudes of members of society can be seen from the 5 main issues for human life. The five main issues include (a) the nature of human life, (b) the nature of the work for a man, (c) the nature of time for a man, (d) the nature of nature for man, and (e) the nature of the relationships between individuals. Based on the five main issues, Thompson et al. (1990) mention that there are 5 perspectives and attitudes of society to socio-cultural life, namely hierarchy, egalitarian, fatalistic, individualistic, and autonomy (the five viewpoints shape and determine the socio-cultural life of the community. 
ISLLAC

Journal of Intensive Studies on Language, Literature, Art, and Culture

Vol. 1 No. 1 September 2017

In relation to the main issues in human life, Sukidin, Basrowi, and Wiyaka (2003) explain the attitude of human life in relation to the nature of life and the nature of the work. According to them, there are three basic views which express the meaning of life for man, namely (a) living for work, (b) living for charity and devotion, and (c) living for fun. Meanwhile, the meaning of work for man is (a) to earn a living, (b) to sustain life, (c) for honor, (d) for satisfaction and pleasure, and (e) for charity worship.

\section{LEARNING SOCIOLOGY}

Sociology in terms of its nature is classified as pure science instead of applied science. Sociology is intended to provide students with competence in understanding sociological concepts such as socialization, social groups, social structures, social institutions, social change and conflict until the creation of social integration (see Basrowi, 2005). Sociology has two basic notions as a science and as a method (J.Biernens de Haan, 1962). As a science, sociology is a collection of knowledge about society and culture systematically arranged based on the analysis of logical thinking. As a method, sociology is a way of thinking to express social reality in society with scientifically responsible procedures and theories.

Learning sociology is intended to develop the ability to understand the phenomena of everyday life. The subject matter includes basic concepts, approaches, methods, and analytical techniques in the assessment of the various phenomena and problems encountered in real life in society. The subjects of sociology are given at the secondary education level as subjects aimed at for the learners to have the ability to (a) understand sociological concepts such as socialization, social groups, social structures, social institutions, social change and conflict until the creation of social integration. ) understand various social roles in social life, and (c) foster social attitudes, awareness, and awareness in community life.

Sociology is the study of the reciprocal relationship between various kinds of social phenomena, such as economic phenomena with religion, the law with morals, the law with economics, communities with their movement, politics and so on (see 
ISLLAC

Journal of Intensive Studies on Language, Literature, Art, and Culture

Vol. 1 No. 1 September 2017

Soekanto.2006). Sociology can also be said to study the science of human interaction in society or group. Humans are social beings who live in groups in society, will be fun and interesting when we learn ourselves in interacting in society. The lessons of sociology examine the various social phenomena, social structures and processes of community life (cf. Saputra and Kreimers, 1987).

Variations of learning methods by an educator will determine the attitudes of pleasure or not learners on a subject. Sociology can be a fun lesson when it is supported by the delivery of materials and attitudes of educators in the learning process and related to the application of educational psychology to sociology lessons which in it discussed the behavior that needs to be raised in the learning process. learning problems, learning problems, how a teacher responds to students differences, measurement and assessment of student learning outcomes and learning process, the understanding of teachers to the talents and interests of students are some studies of educational psychology that can be applied to the lessons of sociology that gives effect to the success of teachers in educating and learners in learning sociology (see Saputra and Creimers, 1987).

Individual differences bring implications for the way teachers manage the sociology learning process. Each learner has differences in differences, such as differences in personality, ability, and learning styles. It is not easy for teachers to pay attention to individual differences in students and follow up with personal learning, but teachers should try to take account of these individual differences in the learning process. One of the important characteristics of effective learning is when learning is able to respond to the individual needs of students in general. The number of differences in students and the teacher's demand to teach at the same time is an obstacle that can be overcome by making variations of methods and learning media.

In sociology learning, teachers can use the discussion together to stimulate the activity of all students in the learning process. In delivering the subject matter through the teacher's lecture is not centered on one or two students who are considered clever, but the teacher must be able to serve all students in the learning process and even give special attention to students who are considered less by 
ISLLAC

Journal of Intensive Studies on Language, Literature, Art, and Culture

Vol. 1 No. 1 September 2017

providing stimulus that is in the form of opinions of students of a cases raised in learning. Teachers should provide opportunities for students to choose how to receive lessons and how to demonstrate their knowledge. In giving assignments, the teacher gives the choice of task type, so students can do the tasks according to their own desires and abilities.

Learning is a process of behavioral change as a result of the interaction of individuals with their environment in meeting their life needs. Learning becomes an important part of the educational process because, by learning, learners can absorb upon what is given during the learning process that followed a better change in the students themselves. Of the various learning theories that develop, the theory of constructivism learning is the most suitable for learning sociology because the purpose of education according to cognitive learning theory is: produce individuals or children who have the ability to think alone to solve every problem faced. Problem-solving exercises are often done through group learning by analyzing problems in everyday life. So in learning sociology students are required to actively solve problems or problems raised by teachers in learning. Discussion groups become one way of learning so that students are able to construct their own knowledge and understanding in learning sociology with the direction and guidance of teachers.

Learning is every effort done deliberately by educators who can cause learners to learn (Morisson, Ross, and Kemp, 2001). Learning takes a very important role in the educational process because it relates how the way and the process of transfer of value from educators to students. There are various learning methods that are suitable for sociology lessons. Q \& A method allows students to be motivated to learn because students have to answer questions asked by the teacher. Students will be able to observe, interpret, conclude, and apply what is gained during the learning process. The occasional tourist work method is needed for the study of sociology because with this method the student can see directly the observed object that is the observation of the social phenomenon in society. Discussion methods are also effective for sociology learning because students are given a problem and asked to 
ISLLAC

Journal of Intensive Studies on Language, Literature, Art, and Culture

Vol. 1 No. 1 September 2017

solve problems in groups. So the students will be active to convey opinions during discussions, with a guidance of the teacher in a discussion will be interesting if it involves new social problems emerging in society. Students will be more enthusiastic and interested to follow the discussion well. Teachers are not only fixated on one of the learning methods, but the teacher must be able to combine the learning method so that the students are not saturated in studying sociology.

\section{ENVIRONMENTAL CONTEXT AS A SOCIOLOGY LEARNING MATERIALS}

Environmental context is an important factor in developing sociology teaching materials. This is based on the reason that in carrying out his life, students will always depend on the environment where he lives. The relationship between the student's life and the environment is not merely manifested as a relationship of human dependence on his environment, but also manifested as a relationship of mutual influence. In other words, humans also helped create the style and shape of the environment. Man, from one side to being part of the environment in which he lives; but from the other side of the environment where he lives is part of himself.

The framework of the foundation that creates and makes man dependent on his environment is culture. Thus, humans, cultures and the environment are the three factors that integrally integrate each other. This statement is rooted in Slotkin's view cited by Adimihardja (1993) that the organism and its environment must be suited to each other. This view implies the need for harmonious and harmonious mutual relations between man and his environment. Thus, a species of living beings will be able to maintain its continuity of existence as long as it feels as an integral part of its environment and is able to adapt to its environment.

The natural environment can provide life's carrying capacity in various forms of possibilities that humans can choose to determine their way of life. According to Forde (1963) that the relationship between human activity with the environment is bridged by the patterns of culture owned by humans. Therefore, the development of 
ISLLAC

Journal of Intensive Studies on Language, Literature, Art, and Culture

Vol. 1 No. 1 September 2017

those choices is heavily dependent on the potential of human culture which, according to historical reality, can flourish rapidly due to its reasonability.

In addition to nature, the environment in which humans live also includes the sociocultural environment, and therefore the human concept must be understood as a bio socio culture (Adimihardja, 1993). In the concept of the bio socio culture, the whole of human knowledge must be used to understand and interpret its environment and experience, and to be the framework of the foundation for the formation of its behavior in the society concerned (Suparlan, 1980). Recognizing this definition, it can be seen as a "control mechanism" for human behavior and actions (Geertz, 1973), or as "patterns of human behavior" (Keesing \& Keesing 1971). In short, culture is a set of rules, instructions, and recipes that consist of a series of cognitive models used selectively by humans who have them in accordance with the environment it faces (Spradley, 1972).

The form of culture is basically a binder of its supporters in the face of its environment. Then the form of culture will be reflected in the pattern of thinking and the totality of behavior of a society in living his life. Rusyana et al. (1988) argued that the form of culture in a society can be approached through 3 perspectives. The first perspective views the form of culture as an adaptive system. In this perspective, the form of culture in a society is a binder of its supporters in facing its environment, both the natural environment and social environment. Second, the form of culture is seen as a cognitive system, which reflects the pattern of thinking and the totality of behavior of a society in treating nature and live his life. As in the third perspective, the form of culture can be viewed as a structural system. According to this perspective, within the culture, there is an orderly order, capable of regulating survival and human life. It is through this culture that people foster interaction with each other, their environment, and pass on the values that are considered beneficial for their survival from generation to generation.

To include environmental factors as a learning medium for students, it is necessary to consider the principles of the planning of learning materials. Sagala (2003) argues that the principles of designing learning materials in general include (1) 
ISLLAC

Journal of Intensive Studies on Language, Literature, Art, and Culture

Vol. 1 No. 1 September 2017

determining what teachers want to teach, when and how to teach them in the implementation of learning, (2) limiting objectives on the basis of specific instructional objectives and defining work execution for (3) developing alternatives appropriate to the learning strategy, (4) collecting and analyzing important information to support learning activities, and (5) preparing and communicating plans and decisions, decisions relating to learning to interested parties.

If the principles are met, theoretically the design of the lesson will give an affirmation to achieve the goals according to the scenario that has been prepared. This is in line with Mulyasa's (2003) opinion that (a) the competencies formulated in the planning of learning materials must be clear, the more concrete the competencies are more easily observed, and the more precise the activities must be done to establish those competencies; (b) planning of learning materials should be simple and flexible, and can be implemented in learning activities, and the formation of student competence, (c) activities developed and developed in the planning of learning materials must support and in accordance with established competencies, and (d) planning of learning that developed should be whole and thorough and clear achievement.

In relation to the above opinion, Hamalik (1980) argues that (a) the draft must be adapted to the availability of resources, (b) the learning organization must always pay attention to the situation and condition of the school community, (c) the teacher as the learning manager must perform the task and function with full responsibility, and (d) human factor as member of organization always faced with limitations.

To create an optimal learning process and quality, based on the development of the learning plan, Gagne and Briggs proposed four assumptions, namely (a) the lesson plan needs to be well developed and using the system approach, (b) the lesson plan should be developed knowledge of the students, (c) the lesson plan should be developed to enable students to learn and establish their competence, and (d) the lesson plans are not made at random, let alone just to meet administrative needs, but 
ISLLAC

Journal of Intensive Studies on Language, Literature, Art, and Culture

Vol. 1 No. 1 September 2017

the lesson plan must be scientifical, comprehensively and can be used as a guide in achieving the formation of student competence in the learning process.

In addition to the principles mentioned above, in sociology learning should include the context of the social environment of children as teaching materials. Teaching based on the surrounding environment will help the child to adjust himself to his surroundings. Theory of school is life and life (Ecole pour la vie par lavie) proposed that bring life into the school so that later learners can live in the community. This view illustrates, for example, that the environment is an important educational / teaching foundation, even with this design a socially oriented model of schooling can be developed.

There are two very closely related terms, but gradually different is nature and environment. The natural surroundings include everything that is around us, whether distant or near, both past and future, unattached to time and place. The environment is something that exists in the natural surroundings that have a certain meaning and/or influence to the individual.

The environment as the basis of instruction is the conditional factor that affects the behavior of the individual and is an important learning factor. The learning environment consists of (1) the social environment is the community, either large or small group, (2) the personal environment includes individuals as a person affects other private individuals, (3) the natural (physical) environment includes all natural resources can be empowered as a source of learning, and (4) cultural environment, including cultural and technological results that can be used as learning resources and can be a supporting factor of instruction (Hamalik, 2003: 194-195).

\section{THE CONDITION OF LEARNING SOCIOLOGY IN TIMOR LESTE}

The sociology lesson is one of the subjects programmed for the students of Senior High School (SMA) Timor Leste. In the high school curriculum structure in Timor Leste, the courses are programmed from class I to class III. The textbooks used are derived from books for Indonesian students and have recently used teaching materials originating from the State of Portugal. The learning process is still very 
ISLLAC

Journal of Intensive Studies on Language, Literature, Art, and Culture

Vol. 1 No. 1 September 2017

conventional, there have been no more innovative class activities. This happens because the teachers who teach the lesson are not entirely teachers who have academic expertise in the field of sociology.

The above problems are the result of Timor-Leste's historical journey from the past. Before as an independent country, Timor-Leste is one of the provinces of Indonesia. When it became part of the Indonesian state, the education system in Timor-Leste became an integral part of the education system in Indonesia. However, after becoming an independent state, the teaching and learning process in TimorLeste has great difficulty because approximately $90 \%$ of junior and senior high school teachers return to Indonesia. To sustain education for Timor-Leste children, the interim government runs the education sector through UNICEF. The big problem facing East Timor's education sector is not only the shortage of teachers but also the lack of infrastructure and books.

Under these conditions, in the early years of independence, Timor-Leste students who are finishing their studies decide to become high school and junior high school teachers, while high school graduates become elementary school teachers. Although teaching and learning activities are running again, the challenge is that these new teachers are mostly not educated teachers or have not attended teacher training. The subjects he teaches are not subjects that match his skills. For example, students majoring in agriculture taught biology and chemistry, students majoring in electronics taught physics and mathematics, students who have basic English courses teaching English subjects. This kind of problem is also experienced by new teachers at the elementary level who are basically high school and junior high school graduates.

The above description reflects that education for the nation's children in Timor Leste still needs serious attention. The development of the education sector in Timor-Leste has not shown results that match the expectations of its people. This can be seen in the existing teaching practices in schools. The existing learning facilities in schools, especially those in the villages, have not met the standards of decent learning needs. The subject teachers teach subjects that do not fit their skills. 
ISLLAC

Journal of Intensive Studies on Language, Literature, Art, and Culture

Vol. 1 No. 1 September 2017

The learning system has not been standardized and is still going on as it is. The curriculum used is still not established and always changing. Thus, the design of the learning model was developed by the teacher in accordance with the capacity of each teacher's ability.

The education system in Timor-Leste is currently under development. Most of the learning done in schools is still dominated by teachers. Learners are treated as empty vessels to be filled with the knowledge the teacher has. Teachers are active subjects, while learners are passive subjects who are submissive and are treated equally. Education is ultimately naive with the teacher providing information that should be accepted as is by the learners. In relation to the importance of education for the nation of Timor-Leste, the RDTL Constitution article 59 "paragraph 1 states that Estadu rekuinece no garante sidadaun hotu nia direitu ba edukasaun no kultura, nune'e mos hari'i sistem encino universal bariku, obrigatoriu no wainhira bele sangati, tuir lei haruka. In verse 4, it is argued that Estadu tenki garante ba sidadaun hotu-hotu, tuir sira nia kapacidade, atu bele betan eskola boot kona ba investigasaun no sientifika no hamoris / haburas arte. The article is the foundation for the government in providing a decent education to all the people of East Timor and ensuring all generations to all participate in education. There is no reason for the state or government not to carry out the mandate of the Constitution, in order to create qualified human resources as a guarantee for sustainable development in the future. However, the manifestation of the law has not shown encouraging results.

The issue of education in Timor-Leste requires continual completion and improvement through the learning process. Continuous improvement efforts in the learning process in schools can be done by referring to the concept of Total Quality Management (TQM). Gostch and Davis (Danim 2002: 102) suggested that one of the rules in applying TQM is the continuous improvement of system performance. For that, evaluation and research activities become very important. Through this evaluation and research activities, accurate data will be obtained to be taken into consideration in decision making with regard to innovative institutional efforts and adjustments to changes. 
ISLLAC

Journal of Intensive Studies on Language, Literature, Art, and Culture

Vol. 1 No. 1 September 2017

In relation to the need for continuous improvement of learning, the performance system of educational institutions in Timor-Leste, especially schools, needs to develop a mature and effective sociological learning. What is meant by mature and effective sociology learning is a program of learning that is steady, simple, complete, and has high visibility to be applied in the effort to achieve the target of education expected. This can be done well if the lesson is based on the socio-cultural context of the Timor-Leste society. Through contextual learning, students will more easily understand the teaching materials because they fit the context of their social environment.

The learning of sociology will be qualified if the teaching materials used contain lesson material designed in accordance with the learning objectives (Sungkono, 2003: 1). Sociological teaching materials taught to students should contain materials, messages, or cultural content in the form of ideas, facts, concepts, principles, rules or theories that can be trained to the students. Thus, students can understand the material easily and able to apply it to solve socio-cultural problems faced in the social environment.

The sociological teaching materials that have the context of the sociocultural environment have an important role for the students. By studying these teaching materials, students have a great opportunity to understand the material well and get a definite answer to the problems faced in their social environment. Sociological teaching materials containing the context of the social environment tangible material description in the form of knowledge, behavior, values, attitudes appropriate to the condition of students and the environment, presented in the sequence of learning activities make enjoying students.

Sociological teaching materials containing socio-cultural environment contexts can serve as a medium capable of transforming people's knowledge, skills, and values of life, culture, and character (moral and personality) to students. In addition, teaching materials can contribute greatly to the achievement of student achievement. The importance of the teaching materials function was put forward by the World Bank Report of 1989, which stated that the level of ownership of books 
ISLLAC

Journal of Intensive Studies on Language, Literature, Art, and Culture

Vol. 1 No. 1 September 2017

and other facilities by learners is positively correlated with the learning achievement it achieves.

Results of studies conducted by Heyneman et al. (1981) indicates that there is a significant correlation between the presence or absence of teaching materials with the learning achievement of learners. The results of this study are confirmed by Patrick (1988), which states that teaching materials are an instructional medium that has a dominant role in the class. Teaching materials also occupy a central role at all levels of education because teaching materials are tools for delivering curriculum materials. Cunningswort (1995), corroborates the explanation by saying that there is no greater effect on the content and implementation of learning activities other than the teaching materials used.

In the learning process, teaching materials have usefulness for students and teachers who teach them. In relation to the usefulness of the teaching materials, Ansary (2002) argues that teaching materials are the framework that regulates and schedules teaching program activities so that the instructional material (1) directs the learning objectives more clearly, (2) shows the serious learning process handling, 3) provide the syllabus, (3) provide ready-made texts and learning tasks, (4) is the easiest way to provide learning materials; (5) make students have a clear learning focus, and (6) keep dependence which is high on the teacher.

\section{CONCLUSION}

The people of Timor-Leste have different cultures from other cultures. The culture is a society-related order of beliefs, attitudes, customs, behaviors, social habits. Culture in the form of order, for the people of Timor-Leste, functioned to manage and meet the needs of his life. Culture is the context that directs the behavior of every individual in the life of society.

The people of Timor-Leste have diverse cultural subsystems, including cultural subsystems for economic communities, regional communities, social communities, and so on. The diversity of the cultural subsystem needs to be understood by every member of the Timor Leste society. To introduce the cultural 
ISLLAC

Journal of Intensive Studies on Language, Literature, Art, and Culture

Vol. 1 No. 1 September 2017

subsystem to the people of Timor-Leste, it can be done through the learning process at school. The subject that teaches the cultural material is Sociology. Sociology is a science that studies the mutual relationship between various kinds of socio-cultural symptoms that exist in society. Sociology studies the socio-cultural interactions of people or groups. The lessons of sociology examine various kinds of social phenomena, social structures and the process of community life.

\section{REFERENCES}

Ansary, H. \& Babaii, E. (2002). A Step Toward Systematic Text book Evaluation. Iran: Shiraz University.

Basrowi. (2005). Pengantar Sosiologi. Ghalia Indonesia.

Beatty, A. (2001). Variasi Agama di Jawa: Suatu Pendekatan Antropologi. Translated by Achmad Fedayani Saefuddin. Jakarta: Rajagrafindo Persada.

Biernens de Haan, J. (1962). Sosiologi Perkembangan dan Metode. Jakarta : PT Pembangunan.

Conklin, J. E. (1984). Sociology: An Introduction. New York: Macmillan Publishing Co., Inc.

Cunningsworth, A. (1985). Choosing Your Coursebook, Oxford: Heineman.

Danim, S. (2002). VisiBaru Manajemen Sekolah: dari Unit Birokrasi ke Lembaga Akademik. Jakarta: Bumi Aksara.

Forde, CD. (1963). Habitat, economy, and society. New York: Dutton.

Geertz, C. (1973). The impact of the concept of culture on the concept of man, in The interpretation of cultures: Selected Essays. New York: Basic Books. 126-141.

Hamalik, O. (2007). Proses Belajar Mengajar. Jakarta: Bumi Aksara.

Hamalik, O. (2009). Kurikulum dan Pembelajaran. Jakarta : PT Bumi Aksara.

Harris, P. R. \& Moran, R. T. (2005). Memahami Perbedaan-perbedaan Budaya. Dalam Deddy Mulyana dan Jalaluddin Rakhmat (Eds.). Komunikasi Antarbudaya: Panduan Komunikasi dengan orang-orang Berbeda Budaya. Bandung: PT Remaja Rosdakarya. 
ISLLAC

Journal of Intensive Studies on Language, Literature, Art, and Culture

Vol. 1 No. 1 September 2017

Heyneman, et all. (1981). Textbooks and Achievement in Developing Countries: What We Know, in Journal of Curriculum Studies Vol. 13, No. 3 (1981) 227-246.

Keesing, F.M \& Keesing, R.M. (1971). New perspectives in cultural anthropology. Chicago: Holt, Rinehart, and Winston.

Keesing, R. M. (1992). Antropologi Budaya: Suatu Perspektif Kontemporer. Translated by oleh Samuel Gunawan.. Jakarta: Penerbit Erlangga.

Koentjaraningrat. (2003). Pengantar Antropologi. Jakarta: Rineka Cipta.

Lewis, R. D. (2004). Komunikasi Bisnis Lintas Budaya. Translated by Deddy Mulyana. Bandung: PT Remaja Roesdakarya.

Liliweri, A. (2003). Makna Budaya dan Komunikasi Antarbudaya. Yogyakarta: LKIS.

Mulyasa, E. (2007). Menjadi Guru Profesional Menciptakan Pembelajaran Kreatif dan Menyenangkan. Rosda. Bandung.

Patrick, J.J. (1988). Highschool Governement Textbook, dalam ERIC DIGEST ED301532, Desember 1988.

Porter, R. E. \& Samovar, L. A. (2005). Suatu Pendekatan terhadap Komunikasi Antarbudaya. in Deddy Mulyana \& Jalaluddin Rakhmat (Eds.). Komunikasi Antarbudaya: Panduan Komunikasi dengan orang-orang Berbeda Budaya. Bandung: PT Remaja Rosdakarya.

Richards, J. C., Platt, J, \& Platt, H. (1993). Longman Dictionary of Language Teaching and Applied Linguistics. London: Longman.

Rusyana, Y., et.al. (1988). Pandangan Hidup Orang Sunda: Seperti Tercermin dalam Kehidupan Masyarakat Dewasa Ini. Jakarta: Dep. P\&K Direktorat Jenderal Kebudayaan. Bagian Proyek Penelitian dan Pengkajian Kebudayaan Sunda.

Sadtono, E. (2002). Perlukah Kita Memahami Kebudayaan Asing? Makalah disajikan dalam Kursus Pramuwisata Muda Jatim di Surabaya pada 7-11 Oktober 2002.

Sagala, S. (2003). Konsep dan Makna Pembelajaran. Bandung : Alfabeta

Saifuddin, A. F. (2005). Antropologi Kontemporer: Suatu Pengantar Kritis Mengenai Paradigma. Jakarta: Kencana.

Snijders, A. (2004). Antropologi Filsafat: Manusia Paradoks dan Seruan. Jogyakarta: Kanisius. 
ISLLAC

Journal of Intensive Studies on Language, Literature, Art, and Culture

Vol. 1 No. 1 September 2017

Spradley, J.P. (1972). Foundations of Cultural Knowledge, in Culture and cognition. Rules, maps, and plans. San Francisco: Chandler 2-38.

Sukidin, Basrowi, \& Wiyaka, A. (2003). Pengantar Ilmu Budaya. Surabaya: Insan Cendekia.

Sumardjo, J. (2005). Ekologi dalam Seni Tardisi, (Online), retrieved from http://www.pikiran-rakyat.com/cetak/2005/1205/17/02.htm, February 6, 2006)

Suparlan, P. (1980). Manusia, Kebudayaan dan Lingkungannya Perspektif AntropologiBudaya. Fakultas Sastra: Universitas Indonesia.

Sutrisno, M. \& Putranto, H. (Eds.). (2005). Teori-teori Kebudayaan. Yogyakarta: Penerbit Kanisius.

Thompson, M., Ellis, R., \& Wildavsky, A. (1990). Cultural Theory. Oxford: Westview Press.

Tomalin, B. dan Stempleski, S. (1998). Cultural Awareness. Oxford: Oxford University Press.

World Bank. (1989). Indonesia: Basic Education Study. Washington DC: World Bank. 